\title{
Influence of Firm Size on CEOs Compensation
}

\author{
Omamo Anne ${ }^{1, ~ *, ~ P e t e r ~ K ' o b o n y o ~}{ }^{2}$, Florence Muindi \\ ${ }^{1}$ School of Business, Jomo Kenyatta University of Agriculture and Technology, Nairobi, Kenya \\ ${ }^{2}$ School of Business, University of Nairobi, Nairobi, Kenya \\ Email address: \\ omamoann@yahoo.com (O. Anne), pkobonyo@uonbi.ac.ke (P. K'obonyo), florence.muindi@uonbi.ac.ke (F. Muindi) \\ ${ }^{*}$ Corresponding author
}

\section{To cite this article:}

Omamo Anne, Peter K'obonyo, Florence Muindi. Influence of Firm Size on CEOs Compensation. Journal of Business and Economic Development. Vol. 6, No. 1, 2021, pp. 23-29. doi: 10.11648/j.jbed.20210601.13

Received: February 5, 2021; Accepted: February 17, 2021; Published: February 27, 2021

\begin{abstract}
This study focused its attention to the link among firm size and CEO compensation of firms listed at the NSE. Previous researchers have identified firm's characteristics that influence the firm's ability to perform. The identified characteristics include firm size, age, reputation and legitimacy. A firm's characteristics could be described through reference to resources the firm owns and by the organization's objectives. Previous researches examined the factors influencing CEO compensation revealed a lack of consensus to the explanation of increases in CEO'S compensation. While most of the studies confirm linkages between organizational performance and CEO compensation, they measured organizational performance using financial indicators of performance, this study investigates the link between firm size and CEOs compensation. The study's population constituted 40 firms listed at the NSE. A mixed design was adopted in the study. Primary data was gathered to capture the opinion of board members on firm size characteristics that determine levels of CEO'S compensation using semi structured questionnaire. Secondary sources of data were used to gather information on financial performance from the financial statement of the listed organizations for 2016-2017 financial periods. Descriptive statistics, correlations, linear, multiple and stepwise regression were applied in analyzing and interpreting the data that was collected. The research revealed that there was significant and positive relationship between firm size and CEOs compensation. The findings of this study are of benefit to board members of organizations in identifying the performance measures that are important to consider when making decisions on CEO remuneration.
\end{abstract}

Keywords: Firm Size, CEO Compensation, Nairobi Securities Exchange, Performance, Firm Characteristics

\section{Introduction}

Currently, the environment businesses operate in have become increasingly complex and global, they are faced with the challenges of managing continuous change, competition, cost constraints, increasing employee demands, legal requirements among others. The management of human resources is seen as a foremost contributor towards helping organizations deal with these challenges by designing ways to effectively increase employee's productivity and commitment. One area of concern to human resource managers is the implementation of employee compensation programs that would satisfy employees' needs as well as contain the costs of labor for the firms [1]. In trying to achieve this, firms have continuously seen the need to tie employees' levels of pay especially the executives to the levels of individual and organizational performance and firm size as well. As such decisions on designing the CEO'S compensation are crucial to an organization since they are accountable for general performance of the organization. One of the concerns in compensation management today is the variation in Chief Executive Officer's compensation. Literature indicates that CEO'S compensation levels vary among firms and industries, nevertheless there is no explanation for these variations [2]. This study seeks to find out explanations to these variations by re-examining the influence of firm size as a determinant of CEO'S levels of compensation.

The debate on CEO'S compensation largely focuses on two viewpoints [3]. That is, whether the CEOS earn their compensation through organizational performance and productivity or whether the CEOS simply capture their compensation through extraction of rent due to weak board 
or poor governance. The first view proposing that CEO'S compensation ought to be associated to observable organizational performance measures like stock prices and earning so as to motivate the CEO'S to enhance organizational performance. The second view asserts that the accessibility of rent and the power to bargain held by CEO'S in excess of board members and shareholders influences CEO'S level of compensation [6]. Equally, empirical studies have been able to establish that organizational size also influences CEO'S compensation and that larger organizations generally offer higher compensation to their CEO'S.

Previous researchers have identified firm's characteristics that influence the firm's ability to perform [5, 8]. The identified characteristics include firm size, age, reputation and legitimacy [9]. A firm's characteristics could be described through reference to resources the firm owns and by the organization's objectives [10] propose that the resources of an organization and its objectives also known as firm characteristics, influences performance of the organizations. The current study focuses attention to firm size as a measure of firm characteristic. In most theoretical and empirical studies where firm size is used, it is described in form of number of human resources in the firm, sum of assets, total sales or market capitalization [14]. The size could be weighted using "sales or market capitalization" [12]. He further observes that sales are the most commonly used measure for firm size. The definition of firm size seems rather easy, a number of differing operationalization of firm size do exist [13]. He proposes that firm size could be described by its physical capacity, the amount of workers available in the organization, the input and output of an organization or the resources available to the firm. He asserts that the number of employees has been proved to be the best indicator of organizational size. The size of an organization can be defined to mean the amount of workers that exist in a firm [15]. The size of a firm stands out as a factor that significantly and positively influences the compensation of CEO'S [16]. Best CEO'S are those who manage the largest firms, since this will help them maximize their influence and financial viability [17]. They forge the position that the compensation of CEO'S will raise with increase in firm size.

Compensation can be defined to include all the returns that employees of an organization get due to their association with the employer through effective performance of their jobs that come in form of finances or benefits [18]. Executive compensation can be viewed as the financial returns which senior managers of organization receive. It constitutes the salaries, the incentives and employee benefits that the executives receive usually offered in line with government or legal requirements [19]. The compensation package of executives constitutes various elements of pay which makes one element drawbacks to be overcome by other elements strengths. Cash bonuses are used to reward executives for their short-term successes in the firm to direct their actions towards achieving the organization's short-term goals. To this end, the cash bonuses are able to overcome the drawbacks of restricted stocks that are awarded for the achievement of long-term goals and do not consider the achievements made in the short-term [20-22]. Scholars vary in their opinion as to whether the increase in executive compensation is a natural one and a product of competition for scarce talent that can increase the value for stakeholders or whether it is only a negative socio occurrence triggered by variations in socio and political environments that extents power to executives to agree on their compensation [19]. Directors of board of organizations have the mandate to determine the levels of compensation that executives receive which is also viewed as an integral component of effective corporate governance.

A major challenge that scholars encounter in trying to understand what really drives CEO remuneration are various components that constitute the total remuneration of CEO'S compensation package. Besides the terms used by researchers, industry and countries are not consistent and tend to cause confusion. A case to mention is that performance share-plans are frequently utilized expressions in the United Kingdom as opposed to long term incentive plans (LTIP) in the US which refers similar type of plan. A basic pay could be provided to CEO'S on a monthly basis and is a constant amount with no risk of non-payment [3]. The CEO'S are also offered a bonus which is at risk of non-payment since it is dependent of organizational performance. The highest bonuses are usually paid out when CEO'S performance exceeds the maximum performance expectations yet bonuses are not offered when the CEO'S performance goes below the minimum performance expectations.

CEO'S are eligible to receive grants of share options within the regulations stipulated for the award of "long term incentive plans". An improvement in worth of share options triggers rise in the company's "share price" and as such there is a possibility of them declining in value just like it is with bonuses. Most CEO'S are legible to receive benefits including membership to clubs, driver, housing allowances, security, education, holidays, medical covers among others. Most organizations also provide the CEO'S with a retirement plan. Going by declarations presented within the reports provided yearly by firms listed at the NSE, CEO'S compensation largely consists of basic salaries, housing allowances, bonuses and long term incentives [23]. Going by the Economic Research Institute study conducted in 2010, CEO'S compensation is determined mainly by compensation committees who largely constitute members of board of directors.

Secondly, CEO remuneration includes incentive plans consisting of cash bonuses which are awarded in lump sum when the operational year ends in order to motivate CEO'S performance. Bonuses act as incentives which are paid to the CEO'S upon attaining previously set goals. Bonuses are linked to accounting measures and are highly associated to the CEO'S specific areas of responsibility. They are aimed at motivating the CEO to pay more attention on the company's key objectives of increasing shareholder value and in turn their own wealth. Bonuses may be provided in association to the achievement of short-term, intermediate term, or even long term goals of an organization. A third CEO 
remuneration constituent is as executive "stock options" which also act as an incentive to the CEO'S. The stock options could be provided in various forms including qualified and non-qualified stock options which are used in a majority of organizations as forms of incentives for CEO'S to drive their behavior towards achieving the interests of shareholders. The qualified stock options provide a tax benefit but they equally have complicated tax consequences. Non-qualified stock options exhibit draw backs for the CEO'S since taxable income is usually reported during the period when the non-qualified options are put into effect without considering whether the stocks have been sold or not. Qualified stock options mitigate this disadvantage since they do not report any income during the period that they are implemented unless the stock is disposed. Executive stock options tend to limit greater risk loathing by providing the CEO'S the drive to increase organizational risk when they allow profitable but otherwise risky projects instead of shunning them.

A fourth constituent of CEO remuneration is restricted stock ownership of an organization which merges the interest of shareholders and the CEO'S. Restricted stock limits the shares that a CEO can own. A common restriction is the imposition of the time period that has to elapse or for the achievement of particular goals before the CEO can cash in the stock. A fifth compensation component for CEO'S is a golden parachute that consists of lucrative benefits that CEO'S are offered in case the organization is acquired by another firm resulting to the CEO'S lose of job. Specifically, the golden parachute items include: stock options, severance pay and bonuses. The sixth and last component of CEO'S compensation constitutes benefits that go to the CEO and including retirement benefit plans, life insurance plans, medical cover, vehicle allowances, membership to clubs, travel re-imbursements, holidays and paid vacations [7].

Problem statement

CEO'S remuneration has been considered to be largely driven by organizational performance based on existing based on existing literature; firms should compensate their CEO'S depending on the gains they generate for the firm. Past researches indicate that organizational performance positively relates to CEO remuneration [23-26]. In the UK context, organizational performance has been found to positively affect CEO's compensation and this applies more with the cash forms of compensation [26]. While other studies showed weak or negative connection among organizational performance and CEO'S pay $[2,8,12]$. Some firm specific characteristics like size can be thought of as influencing executive compensations. The main objective was therefore to establish influence of firm size on CEO'S compensation.

\section{Literature Review}

Previous researches generally indicate a strong association among size of a firm and CEO rewards. CEO compensation has tight connection to organizational size when size is measured by sales and it is loosely linked to profits [7]. This kind of association indicates that increases in sales will lead to CEOS being paid more than increases in profits. As such the CEO will work harder towards maximizing sales as opposed to maximizing profit. Organization size affects the complexity of jobs and organization's ability to pay leads to influence of decisions on CEO remuneration [10]. However, the foregoing arguments have been contradicted and revealed high link amid CEO remuneration and organizational profits rather than sales levels [14, 19, and 21]. This he justified by arguing that business organizations ultimate purpose is to maximize profits and deliver a return to shareholders This implies that CEO'S who contribute efficiently to profit maximization would be rewarded with high compensation. Other studies show high association for larger organizations and CEO'S holding higher quality skills, qualifications and diverse characteristics and be compensated in view of the same [13].

An increasing literature links increase in CEO'S compensation to increase in firm sizes and scale effects [9]. Larger firm's value more talented CEO'S and are willing to offer higher levels of compensations so as to match the efficient labour market of competent CEO'S. This is encouraged because small improvements in CEO'S talents may translate to high increase in "value of the firm" conversely leading to enhancement in compensation brought about by the large scale of operations that the CEO is in charge of [11].

As noted, organizational outcomes and size hold as most consistent factors that influence CEO'S compensation as found in previous studies [15, 17]. Large firms provide higher CEO compensation and justify it by greater responsibility the CEO holds, greater complexity in the CEO'S job, larger scale of operations in the firm and equivalently higher compensation offered to CEO'S in other large competing firms. Equally, more profitable firms offer their CEO'S higher compensation and they justify it as a reward for the CEO'S strong managerial performance. When firms post higher profits, the CEO'S task to legitimize their compensation increment is rather straight forward. However, when organizations are smaller or organizational performance is poorer it would be an uphill task to legitimize compensation increases.

Huge body in empirical evidence associates increases in CEO'S compensation to increase in organizational size [18]. The flexibility of CEO'S compensation to firm size could be estimated at 0.25 implying that $10 \%$ increase in the size of an organization will trigger a $2.5 \%$ growth in CEO'S compensation. The direction of this kind of relationship is justified by the fact that CEO'S or larger organizations need to be offered compensation that are commensurate to the greater economic effects of their dealings [19]. Growth in literature continues to provide evidence to association amid CEO'S compensation and organizational size. The productivity expectations for a $\mathrm{CEO}$ grows with increase in firm size due to the reason that the CEO'S of large firms make decisions to utilize a larger pool of employees and 
other resources [22]. Larger firms will look out for more talented CEO'S in the already competitive labour market and will therefore compensate the CEO'S based on their productivity, firm size and ability. As noted, the reason for the high association among CEO remuneration and organizational size owes to greater organizational complexity, more stratification and larger number of human resources that exist in organizations larger in size $[15,19,21]$.

There are theories which propose that changes in firm characteristics like technologies, products, market size also act as a major factor that influences CEO'S effort, talent and organizational value and this in turn affects the level of CEO'S compensation [16]. Increase in organizational size is prone to result in enhancement of CEO'S effort, thereby result to a rise in CEO'S incentive compensation [12]. In opposition to the "managerial power approach" to explain CEO remuneration, there is growth in literature at associate CEO'S compensation increase to increased demand for CEO'S scarce talent [12]. They further proposed for in CEO rise in remuneration being attributed to growth in firm size which expands the scale of operations Such that highly talented CEO'S are of more value to large firms and so larger firms should be ready to offer hefty rewards to CEO to much capabilities of the CEO and win the war for talent in a competitive market [15]. As noted, CEO talent has an incremental power on organizational outcome [17]. CEO compensation should change proportionately with changes in firm size. They use this to expound on continuous growth in CEO'S average compensation between the year 1980 and 2003 which also recorded a similar growth in average market capitalization. Moral hazard problems are usually higher in larger organizations leading to higher CEO incentives as the organization grow in size [17].

Firm size receives interest in most of preceding research on CEO remuneration. Basic assumption behind this is that larger firms will have muscle to reward CEO highly because of their inferred large size in business causing greater gains $[19,22,25]$.

Literature and academic works indicates high association amid firm size and CEO remuneration. CEO remuneration is strongly connected to organizational size when weighed using total sales yet the association weakens if size is weighed using organizational profits [15]. This can be interpreted to mean that growth in sales will trigger CEO'S rise in compensation as opposed to increased profit. Similarly organizational size highly associates to complexity in the CEO job and the employer's ability to pay [6]. Other studies still indicated that organizational size is given high consideration in determining CEO reward especially when organizational size is weighed using "total assets" [9]. Larger organizations by their nature would tend to look out for CEO'S who possess high quality decision making skills, experience, and training and as such would be forced to offer such CEO'S higher levels of compensation [5].

A weak connection among compensation for executives and organizational size. This goes against suggestions by initial researches and instead concluded that adjustments in size don't necessarily influence CEO remuneration [8]. The connection among CEO remuneration to organizational size is loose especially if organizational size is weighed using net sales [11]. Still other researchers measured firm size using sales and found a tight association among organizational size and CEO remuneration $[12,16,18]$. Variations in outcome of studies examining connection among organizational size and CEO remuneration suggest that further research could provide more clarification concerning this association. Organizational size and profitability are deemed to be the key drivers consistently moving CEO reward decisions as shown in previous research. Large firms usually justify the high rewards offered to CEO by citing the immense responsibilities that the CEO has, the wide span of operations, complexities that come with the CEO'S job and achieving external equity by matching high levels of CEO'S compensation as offered by other firms. Higher compensation in firms with higher gains can be justified as payment towards strong managerial outcomes. In large, profitable firms, the CEO'S task in legitimizing high compensation is relatively straightforward [17].

\section{Methodology}

This study adopted a descriptive cross-sectional design, which involved identification and description of phenomena or characteristics linked with a subject population (who, what, when, where, and how of a topic). The approach helped to reveal if any associations exists between the different variables, so as to establish if the variables are independent (or unrelated) and if there is no association, then to establish the strength or magnitude of the relationship. Questions are carefully selected, arranged and accurately asked of each board member. Cross-sectional studies are conducted once or at one point in time [15].

A descriptive cross-sectional design enabled the researcher to establish any relationships between and among organizational performance, CEO'S power, firm size and CEO'S compensation of firms listed in NSE. Financial data was collected for the period 2016/2017. The design was chosen considering the type of data and the analysis that is carried out.

The applicable population of the study encompassed all listed organizations at NSE. According to the NSE Handbook 2016, the total number of companies listed at the browse was 40. This study was therefore a "census survey" of all listed companies shown in appendix III. Data on financial performance was obtained from financial reports filed with capital markets authority (CMA). Data on firm size was also collected from the source.

The study applied both "primary and secondary data" to test hypotheses. "Primary data" on organizational performance, CEO'S power, and CEO'S compensation collected utilizing "structured questionnaire". The questionnaire was administered by the researcher- to the firms' board of directors with assistance from the company secretaries who are also the secretaries to the board. The 
questionnaire gathered data on the Organizational size and CEO'S compensation. The questionnaire was on "Likert-type statements anchored on five-point rating scale ranging from none (1) to very high (5)". This approach was also applied in related studies $[14,17,19]$. Secondary data on firm size (total number of employees) and organizational performance "return on assets" was retrieved from organizational "financial reports".

\section{Results and Discussions}

Board members were asked to provide their opinion in the extent to which they considered the power of the CEO in determining CEO'S compensation. Nine (9) items were used to measure this variable.

Table 1. Respondents score on CEO'S power.

\begin{tabular}{|c|c|c|c|c|c|c|c|}
\hline CEO'S compensation & $\begin{array}{l}\text { very large } \\
\text { extent }\end{array}$ & $\begin{array}{l}\text { large } \\
\text { extent }\end{array}$ & $\begin{array}{l}\text { moderate } \\
\text { extent }\end{array}$ & less extent & not at all & Mean & $\begin{array}{l}\text { Standard } \\
\text { deviation }\end{array}$ \\
\hline $\begin{array}{l}\text { The managers of the different branches of the firm } \\
\text { receive different pay }\end{array}$ & $1(2.4)$ & $6(14.3)$ & $35(78.6)$ & $2(4.8)$ & $2(4.8)$ & 4.7500 & 0.70711 \\
\hline "Percentage of shares owned by the CEO" & $1(2.4)$ & $4(9.5)$ & $7(16.7)$ & $18(42.9)$ & $12(28.6)$ & 3.8000 & 1.01779 \\
\hline $\begin{array}{l}\text { The percentage of non-executive members } \\
\text { increases growth of the firm }\end{array}$ & $12(28.6)$ & $28(66.7)$ & $2(4.7)$ & & & 4.7000 & 0.46410 \\
\hline $\begin{array}{l}\text { The frequency with which the board has turned } \\
\text { down the CEO request for revision of } \\
\text { compensation is high }\end{array}$ & $5(11.9)$ & $19(45.2)$ & $16(38.1)$ & $2(4.8)$ & & 4.1500 & 0.94868 \\
\hline $\begin{array}{l}\text { The number of times the CEO has successfully } \\
\text { negotiated with the board for improvements in } \\
\text { compensation following growth of the firm }\end{array}$ & $1(2.4)$ & $5(11.9)$ & $6(14.3)$ & $11(26.2)$ & $19(45.3)$ & 3.9500 & 1.15359 \\
\hline Board members appointed after CEOs appointment & $26(61.9)$ & $14(33.3)$ & $2(4.8)$ & & & 4.3500 & 0.48305 \\
\hline $\begin{array}{l}\text { The CEOs chairs meeting of all branches of the } \\
\text { firm and enjoys allowances }\end{array}$ & $1(2.4)$ & $9(21.4)$ & $13(31)$ & $11(26.2)$ & $8(19.1)$ & 3.3000 & 1.06699 \\
\hline
\end{tabular}

The" results in Table" 1 provide an average "mean score" of 4.1778 on CEO'S compensation. This indicates that firm size is considered to a less extent in deciding the CEO'S compensation. On the item of how frequently the CEO chairs the board meetings, board members agreed that it did not contribute at all in determining CEO'S compensation (Mean 4.75, SD 0.70711) implying that CEO's duality does not exist among firms listed at the NSE hence limiting the CEO's power to influence the board over their compensation decisions. The results indicated that board members disagreed that the portion of shares owned by the CEO contributes to CEO's power (Mean 3.8, SD 1.01779). Board members also indicated the percentage of external board members was none contributory at all in determining CEO'S compensation (Mean 4.7, SD 0.46410). The results indicated that board members disagreed that the frequency with which the board turned down the CEO request for revision of compensation contributed to CEO's power (Mean 4.15, SD 0.94868).
The results indicated that board members disagreed that the number of times the CEO has successfully negotiated with the board for improvements in compensation contributed to CEO's power (Mean 3.95, SD 1.15359). The results also revealed that board members disagreed that the number of board members appointed after CEOs appointment contributed to CEO's power (Mean 4.3500, SD 0.48305 ). The results indicated that board members disagreed that length of period current board has served contributed to CEO's power (Mean 4.325, SD 0.4743). The only item that received moderate consideration was the number of times that the current board revised CEO'S compensation upwards though board members differed on their opinion (Mean 3.3, SD 1.06699). The results indicated that the percentage the board has revised CEOs package did not contribute to CEO's power (Mean 4.5750, SD 0.50064). The findings generally indicate that the CEO's do not have power to influence decisions of their compensation.

Table 2. Inferential results for firm size and CEOs compensation.

\begin{tabular}{|c|c|c|c|c|c|c|}
\hline \multicolumn{7}{|c|}{ Model Summary } \\
\hline Model & $\mathrm{R}$ & R Square & & Adjusted R Square & Std. En & timate \\
\hline 1 & .464 & .215 & & .196 & 19.469 & \\
\hline \multicolumn{7}{|c|}{ ANOVA } \\
\hline \multicolumn{2}{|c|}{ Model } & Sum of Squares & df & Mean Square & $\mathbf{F}$ & Sig. \\
\hline \multirow{3}{*}{1} & Regression & 4163.269 & 1 & 4163.269 & 10.983 & $.002^{\mathrm{b}}$ \\
\hline & Residual & 15162.354 & 40 & 379.059 & & \\
\hline & Total & 19325.622 & 41 & & & \\
\hline
\end{tabular}




\begin{tabular}{|c|c|c|c|c|c|}
\hline \multicolumn{6}{|l|}{ Coefficients } \\
\hline \multirow{2}{*}{ Model } & \multicolumn{2}{|c|}{ Unstandardized Coefficients } & \multirow{2}{*}{$\begin{array}{l}\text { Standardized Coefficients } \\
\text { Beta }\end{array}$} & \multirow{2}{*}{$\mathbf{t}$} & \multirow{2}{*}{ Sig. } \\
\hline & B & Std. Error & & & \\
\hline \multirow{3}{*}{$\begin{array}{lc}1 & \text { (Constant) } \\
\text { a. Dependent } & \text { FS1 } \\
\text { Variable: CC }\end{array}$} & 8.112 & 3.026 & & 2.680 & .011 \\
\hline & .001 & .000 & .464 & 3.314 & .002 \\
\hline & & & & & \\
\hline
\end{tabular}

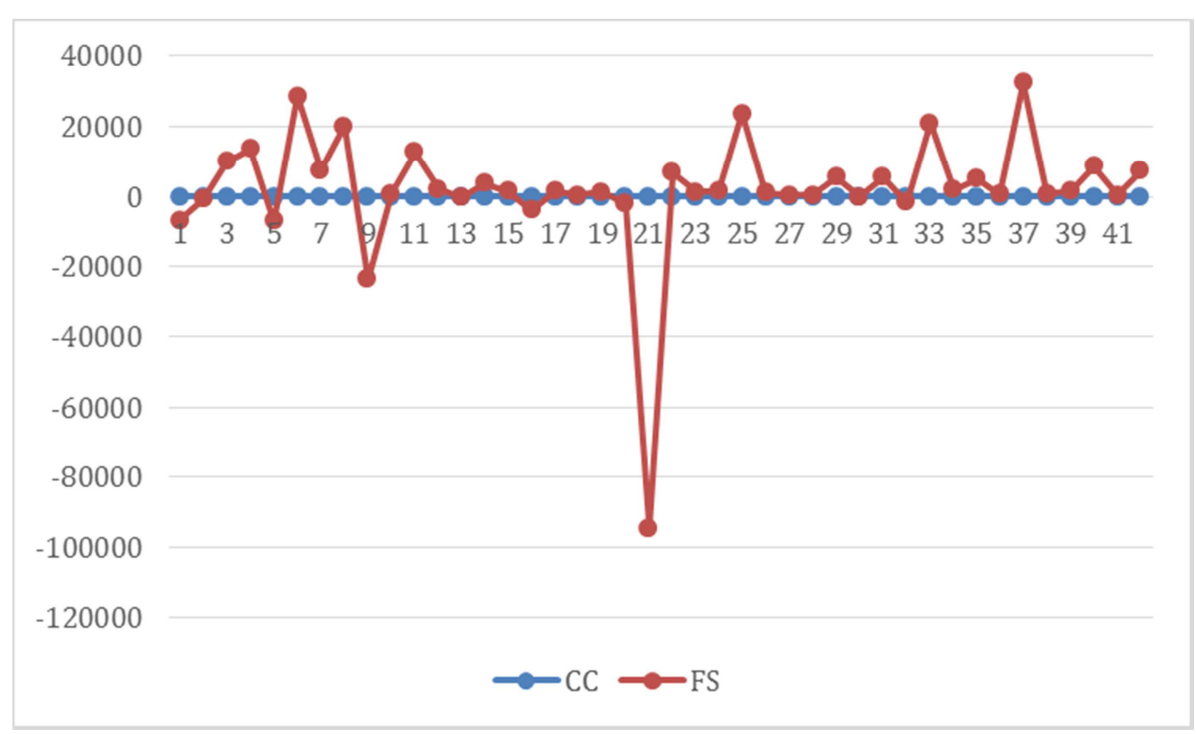

Figure 1. Graph of CEOS Compensation and Firm size.

\section{Conclusions and Recommendations}

Results indicated that the firm size strengthened the link among the CEO compensation and organizational performance variable by explaining $21.5 \%$ of difference in CEO remuneration, $\left(\mathrm{R}^{2}=0.215\right)$. The initial model for link among organizational performance and CEO'S compensation revealed that firm size explained $21.5 \%$ of variations in CEO'S compensation.

CEO'S compensation has been on a continuous rise and there has been a growing concern for the explanation of the same. The current study sought to investigate influence of firm size on the determination of CEO compensation. Results of the study revealed that firm size had significance effect on CEO'S compensation. Therefore board directors of firms listed at the NSE should consider a compensation policy on $\mathrm{CEO}$ remuneration requiring that determination of $\mathrm{CEO}$ compensation and should put into consideration the performance of organizations. Further the policy should specify the elements of organizational performance and the weights attributed to them in determining how much to pay the CEOS. This includes the balanced score measures of financial indicators, "customer satisfaction", learning and development and internal processes. The study further implies that CEO'S should enhance overall performance of organizations by putting into consideration the key drivers of performance as opposed to firm size alone.

As noted, most research on CEO compensation have failed to adequately consider the vast power that CEO'S may have in influencing their own compensation by exercising various forms of power at their disposal [21]. It is of strategic importance for an organization to understand the firm size needs and the authority that CEOs exert due to expansion of firms. This kind of understanding is important to shareholders, corporate directors and public policy makers who attempt to associate CEO'S compensation to corporate performance.

\section{References}

[1] Abed, S. Suwaidan, M. \& Slimani, S. (2014). The determinants of Chief Executive Officer Compensation in Jordanian Industrial Corporations, International Journal of Economics and Finance; Vol. 6, pp 110-118.

[2] Aduda, J. (2011). The Relationship between Executive Compensation and Firm Performance in the Kenyan Banking Sector, Journal of Accounting and Taxation, Vol. 3 (6), 130139.

[3] Agrawal, A. \& Charles, R. K. (1998). Managerial Compensation and the treat of Takeover. Journal of Financial Economics, 47: 2, pp. 219-39.

[4] Alchian, A. \& Demsetz, H. (1972). Production, information costs, and economic organization. American Economic Review, 62: 777-795.

[5] Allen, M. P. (1981). Power and Privilege in the Large Corporation. Corporate Control and Managerial Compensation. American Journal of Sociology 86: 1112-1123.

[6] Brown, J., \& Fraser, M. (2006). Approaches and perspective in social and Environmental Accounting; An overview of the conceptual landscape, Business Strategy and Environment. Vol: 15: 103-117. 
[7] Buigut, K., Soi, N. \& Koskei, I. (2014). Determinants of CEO Compensation Evidence from UK Public Limited Companies, International Journal of Business and Management, Vol. 10, No. 1; 2015.

[8] Bushman, R. M., Indjejikian, R. J. and Smith, A. (1996). "CEO compensation: the role of individual performance evaluation", Journal of Accounting and economics, Vol. 21, pp 161-193.

[9] Ciscel, D. H. (1974). 'Determinants of executive compensation'. Southern Economic Journal.’ 40, 613-617.

[10] Chalmers, K., Koh, P. S., Stapledon, G. (2006). 'The determinants of CEO compensation. Rent extraction or labor demand?' The British Accounting Review 38, 259-275.

[11] Charan, R. (2005). Boards that deliver, Jossey-Bass, San Francisco, CA.

[12] Cheng, S., Venky, N. \& Madhar, V. R. (2001). Control versus Risk in Stock-Based Incentives: Evidence from Antitakeover Regulation. Working paper, University of Michigan Business School.

[13] Chingos, P. T. (2004). Responsible Executive Compensation for a New Era of Accountability. Wiley.

[14] Chung, Y. (2010. CEO Ability, Pay, and Firm Performance. JEL Classification: G34, J24, J33.

[15] Certs, S. T., Daily C. M., Cannella, A. \& Dalton, D. (2003). Giving Money to Get Money: How CEO stock option and CEO Equity Enhance IPO valuations, The Academy of Management Journal, Vol. 46, Academy of Management.

[16] Collingwood, H. (2009). DO CEO'S matter? June 25009 Atlantic Magazine, on line Edition.

[17] Eisenhardt, K. M. \& Schoonhoven, C. B. (1996). Resourcebased view of Strategic alliance formation; Strategic and social effects in entrepreneurial firm, Journal of Organization Science Vol. 7, Pg. 136-150.

[18] Epstein, M and Roy, M. (2002). Measuring and improving the Performance of Corporate Board. The Society of Management Accountants of Canada, Hamilton.

[19] Epstein, M. and Roy, M. (2002). Evaluating and Monitoring CEO performance: evidence from US compensation committee reports, The International Journal of Business in So and Country Institutional Development. Working paper.

[20] Farmer, M. (2008). Chief Executive Compensation and Company Performance: a weak relationship or measurement weaknesses? Kingston University, UK.

[21] Finkelstein, S. \& Hambrick D. C., (1989). Chief Executive Compensation: a study of the intersection of markets and political processes, Strategic Management Journal Vol. 10.

[22] Fleming, G., \& Stellios, G. (2002). CEO compensation, Managerial Agency and boards of directors in Australia. Accounting Research Journal, 15 (2), 126-145.

[23] Fong, E. A. (2004). 'Chief Executive Officer (CEO) Responses to CEO Compensatin Equity.' University of Florida.

[24] Caroline, Y. Parbudyal, S. Jing, W. (2019). The effects of firm size and firm performance on CEO pay in Canada: A ReExamination and Extension.

[25] Fabián Blanes, Cristina de Fuentes \& Rubén Porcuna (2020) Executiveremuneration determinants: New evidence from meta-analysis, Economic Research-Ekonomska Istraživanja, 33: 1, 2844-2866, DOI: 10.1080/1331677X.2019.1678503.

[26] Mary S. Hill, Thomas J. Lopez, Austin L. Reitenga, (2016) CEO excess compensation: The impact of firm size and managerial power, Advances in Accounting Volume 33, 2016. Pages 35-46, ISSN 0882. 